\title{
THE MAKING OF STATUTORY INSTRUMENTS
}

\author{
JEREMY S. WILLIAMS*
}

Professor Williams discusses Parliamentary procedure in the creation of subordinate legislation while also treating the substance of statutory instruments. Canadian procedure is compared with that of other Commonwealth countries. An evaluative review of the present system is put forth in light of the recent Report of the Special Committee on Statutory Instruments. Consideration of the changes and reforms suggested by the Special Committee is accompanied by an analysis of the issues and choices involved in any reform that may be undertaken. This article presents a comprehensive statement by a theoretical examination of contemplated reform in this area of the law.

Statutory instruments have proved to be useful and necessary measures of control. They are one of the most important means of leaving Parliament a free hand to decide major questions of policy without being forced to commit itself to detailed rules. The use of subordinate legislation has the merit of being able to reflect quickly scientific advances and master technical details which would be tedious, if not impossible, were it left to Parliament. The time factor as well as the impracticality of the whole Parliamentary body coming to a conclusion in some circumstances makes it vastly more convenient for certain functions to be delegated to a subordinate. ${ }^{1}$ For these reasons it would be invidious for Parliament to legislate directly upon the standard specifications of tins of sardines or the working conditions in coal mines. Another factor which reinforces the need for delegated legislation is that of secrecy; whether for reasons of national importance such as defence or for reasons of discretion such as revealing the salary of a public official. If an appropriate body may be found it would be wise to leave Parliament free to "decide material questions affecting the public interest". ${ }^{2}$

In any case the delegation of power is inevitable. As a governmental practice it appears to be inclined to increase. Both legislative and judicial functions are being entrusted to the Executive to a great extent. The usual repositories of wide or general powers are Ministers or the Governor in Council, of more restricted and narrow powers subordinate public servants. The general rule appears to be that the wider the power delegated the nearer to the Government it must be exercised. In any case, the delegated power should be exercised by an authority which commands the national confidence.

In view of these considerations the most practical course seems to be to provide sufficient safeguards to discourage the abuse of power. ${ }^{3}$ In 1968 the House of Common Special Committee on Statutory Instruments was established under the chairmanship of Mr. Mark MacGuigan

- LL.M. (Sheffield), B.C.L. (Oxon.), Assistant Professor, Faculty of Law, The University of Alberta.

1 See the Report of the Committee on Ministers' Powers (1932; U.K.) Cmd. No. 4606 at 23 (1932) where it is stated that. "Parliament nowadays passes so many laws every year, that it lacks the time to shape all the legislative detalls." It has long been the case in England that details have been left to be settled departmentally and the procase in England that details have been left to be settled departmentally and the pro Thring. Practical Legislation (1887) at 13.

3 This position was strenuously advanced by Lord Hewart in his book The New Despotism (1929). See also Crick, The Reform of Parliament (1965) at 156 and Carr. Delegated Legislation 4 (1921). 
to enquire into the safeguards presently existing in Canadian law and into whether there should be any reform or extension of them. It may, therefore, be useful to examine certain matters relevant to the making of statutory instruments for it may be expected that the Committee will recommend certain reforms.

\section{The Substance of Statutory Instruments}

Statutory instruments may be infinitely various in their content. Many of them govern administrative detail and so are not worthy of inclusion in an Act of Parliament. Others are essentially substantive legislation but cannot be included in an Act because of the rapidity with which they may need to be changed or some other reason. In short, statutory instruments may be infinitely various in substance. They may also be judicial, executive or legislative in character, although our present concern is primarily with regulations or subordinate legislation.

\section{Enabling Legislation}

The principle that Parliament is omnipotent within certain constitutional limits allows Parliament, by statute, to delegate all or any of its functions to another body. There is a natural reluctance on the part of legislators to formally divest Parliament of the functions it normally exercises. This attitude is encouraged by informed members of the public who would prefer to continue to see general rules being made by elected representatives rather than a bureaucracy. The chief danger resulting from the proliferation of enabling legislation is a lack of control by either the public itself or a body ultimately responsible to the public. Adequate supervision by the public or such body as a regular matter would tend to obviate this difficulty. This allows citizens to be involved, at least in an indirect way, in the making of delegated rules and regulations. Thus the citizen is permitted to participate, through his Member of Parliament or other representative, in a continuing way with enactment of subordinate rules. Therefore, it is important for the enabling legislation to provide an appropriate method for the making of subordinate rules. If such rules are of general application or involve a major question of policy either the Government or Parliament ought to pass upon them at some stage in their enactment.

The citizen has other general rights which might be relevant to delegated legislation and of which he ought not to be divested. Some care should be taken to see that the enabling statute does not remove from members of the public any rights which they would have if the legislation involved were not delegated by Parliament. The choice of Parliament need not consist solely of the two extremes of a completely unfettered power to make delegated legislation and no power at all to do so. There are several methods of allowing a subordinate legislator to make rules and regulations subject to some control. The appropriate form of control may be embodied in the terms of the enabling legislation. Various forms of control involve the elicitation of permission or the possibility of a veto from one or other of the Houses of Parliament. A scrutiny committee might also fulfil some of the functions of a public surveillance.

When considering enabling legislation it should be noticed that the insertion of a Parliamentary control has certain disadvantages. Parlia- 
mentary control is usually coupled with an increased opportunity for debate of the statutory instrument in Parliament. This may tend to jeopardize the Government on many occasions more than it would be possible to do so at the present time. Regulations are currently most often made by the Governor-in-Council and therefore the Government as a whole takes responsibility for them. If a vote is recorded against the Government or a resolution disapproves of a statutory instrument it is to be regarded as a vote of "no confidence" in the Government and should result in their overthrow."

Without infringing upon the omnipotence of Parliament it might be useful for Parliament to be informally restrained from setting up regulation-making bodies in large numbers. This might be effected by guidelines to be borne in mind by the legislators. One matter which might be impressed upon the minds of the legislators is that enabling Acts generally ought not to exclude the jurisdiction of the courts. While it is a presumption of the general law that statutes are not to be construed so as to restrict the jurisdiction of superior courts, ${ }^{5}$ it is within the power of the Parliament to restrict or exclude the jurisdiction of the courts. It should be remembered that such a restriction or exclusion is a large deprivation because appeal to the courts is almost the only avenue left to the citizen. In the same condition would be a restriction or exclusion of the right of an Ombudsman or Parliamentary Commissioner to enquire and report. Such an official, although he usually has no power to hinder or control the operation of a general regulation in those jurisdictions in which he has been appointed, has the power to enquire into the specific application of such general regulations. Similarly the powers of search and seizure should only in the clearest circumstances be incorporated in an enabling Act. Nor should the power to amend or add to the enabling Act or other Acts lightly be given. Consideration should be also given to the question of whether it would be more appropriate to make a charge on the public directly, or on the public revenue, in the enabling legislation, by delegated rule or under the Estimates system. It would also be undesirable for an Act to confer so wide a discretion on a Minister or other regulation-making body that it is almost impossible to know what limit Parliament did intend to impose. Exceptionally, such powers may justifiably be conferred in an enabling statute.

The function delegated may often amount only to the "appointment of a day" or the "fixing of a standard" but in such a case the function should not normally be described as regulation-making. Although the exercise of this function may affect a large segment of the public the limits within which the function may be exercised are closely circumscribed. ${ }^{\circ}$ Such a narrow power would rarely give cause for public alarm. Another method of delegating authority is to allow a particular sort of regulation to be made. This method of delegation involves a

4 However, opinions on the strength of this convention vary. See Driedger, The Composition of Legislation (1957) at 151; Dicey, The Law of the Constitution (10th ed. 1959) at 26 et seq.

5 See Driedger, The Composition of Legislation (1957) at 127.

6 Modern English delegated authority seems often to be of this type. Thus the Donoughmore Committee on Ministers' Powers in its Report Cmd. No. 4060 (1932) at 65 recommended that, "The precise limits of the law-making power which Parliament intends to confer. . . should always be expressly defined in clear language by the statute which confers it; when discretion is conferred, its limits should be defined with equal clearness". 
description of the regulation in the enabling statute. Whether this type of delegation should give cause for alarm will depend upon how vague the description is. Thus an enabling statute which provided that "The Minister may make regulations prohibiting interprovincial trade in wheat" would probably not give cause for alarm because the limits of what the Minister may do are clearly expressed and relatively narrow. It might be otherwise if the Minister were empowered to "specify the terms of interprovincial trade in grain". The regulations which might be made under the latter power might not always be predictable.

Though delegation of a rule-making function would appear to be inevitable there are various alternative procedures which might be more appropriate in certain cases. ${ }^{7}$ In those situations, other, more appropriate means of securing conformity of conduct might include:

(a) Embodiment of the contemplated rule in a statute. ${ }^{8}$

(b) Establishment of a procedure having no legislative force. Contravention of such a procedure might be used as prima facie evidence of a breach of duty for various purposes relevant to the civil law.)

(c) Judicious use of financial incentives.

(c) Establishment of a procedure with which all given acts of a designated type must conform if they are to have any force and effect in law.

The choice of a method designed to secure conformity of conduct should be dictated only by considerations of what will best accomplish the end -without offending the sensibilities of members of the public. It is suggested that in the past an all too ready reliance on subordinate legislation has been exhibited, without consideration of these alternatives.

\section{Formulation of Statutory Instruments}

The making of regulations or rules differs from administrative decision-making in the generality of the applicability of the rule. A rule is such by virtue of its being capable of applying to more than one subject whereas a decision is usually only capable of specific application. Usually, too, a rule differs from a decision in that it is capable of applying to the future. ${ }^{9}$ The differences between legislation and adjudication are much less well defined when carried into the executive or administrative functions. Administrative action very often partakes of both legislative and executive characteristics. Some such action is complicated further by the addition of a quasi-judicial aspect.

The choice of the appropriate person or body for the making of a statutory instrument, and the method whereby it is made, depend upon many factors, most of which spring from the nature of the instrument itself. The generality of the rule in question and its longevity will influence the decision as to whether an official or a board which may deliberate and consult is to be empowered to make the rule in question.

7 Officials of the Department of Transport would prefer some alternative to be employed in particular cases. See Minutes of the Special Committee on Statutory Instruments (1969) at 173.

8 Embodiment in a statute might be the solution for regulations made under $s .5(t)$ of 173 (1969).

173 (1969). the Immigration Act R.S.C. 1952, c. 325 where these regulations do not have to be ments (1969) 179 et seq.

- See Fuchs, Procedure in Administrative Rule-Making, (1938) 52 Harv. L. Rev. 259 at 260 . 
The character of the parties affected and the type of coercion to be employed to enforce the rule will also have some bearing upon the selection of a subordinate legislator. The dictates of practicality necessitate that many administrative decisions and orders will have to be made by single officials on the basis of administrative knowledge or after a merely informal investigation.

The sort of procedure to be used by a tribunal invested with the power of making rules will depend to a large extent on the composition of the tribunal which, in turn, depends on the nature of the rules to be made. The procedure used may be formal or informal and it may be divided into two broad categories; the investigation system and the adversary procedure. Either of these two procedures may result in a rule. In general, it has been the former method which has been used in Canada by regulation-making authorities established under Federal statutes. The regulation-making authority almost always has the assistance of a draftsman in the formulations of draft regulations. In practice, the Legal Adviser to the Privy Council Office then examines the draft to ensure that it is in accordance with the established standards of form and draftsmanship and to ascertain that it is consistent with the Bill of Rights. ${ }^{10}$

The procedure for recording statutory instruments which is currently used in the Canadian Federal Government appears to be quite adequate. In accordance with s. 3 of the Regulations Act ${ }^{11}$ the regulation-making authority is bound to send copies of the regulation ${ }^{12}$ to the Clerk of the Privy Council. The Clerk of the Privy Council is then to certify a copy of the regulation and to assign a number to the regulation. Non-compliance with this procedure does not, however, invalidate the regulation.

\section{Enactment of Statutory Instruments}

Present methods employed to give the force of law to statutory instruments are diverse. They vary according to the procedure specified by the enabling legislation. Such enabling legislation usually appoints a body or person to make subordinate rules. Such body or person may be already in existence or it may be established by the Act giving the power to make such rules. The enabling legislation will often prescribe an appropriate procedure for the enactment of subordinate rules. They may, as a result of the terms of the Act, be invested immediately upon being made with statutory force or else further formalities may be requisite.

The methods presently employed for giving the force of law to delegated legislation in Canada vary but may be generally classified. Most rules become valid without reference to either Chamber of Parliament. These are largely made by the Governor-in-Council and by Ministers of Government Departments. Stautory instruments made by either the Governor-in-Council, by the Minister, or by certain Boards and Officials responsible for the making of certain statutory instruments are unaf-

10 The authority for this examination is to be found in regulation 4 pursuant to 8 . 9 of the Regulations Act, R.S.C. 1952, c. 235 and $s .3$ of the Canadian Bill of Rights S.C. 1960 c. 44.

11 R.S.C. 1952 , c. 235.

12 The definition of a regulation according to $s$. 2 of the Regulations Act is very wide, but may be further widened. 
fected by the wishes of the House of Commons or the Senate subsequent to the passage of the enabling legislation. Such statutory instruments could, however, always be reversed by Act of Parliament. In very few cases does either Chamber of Parliament have a part to play in the making of stautory instruments. However, all regulations are required by the Regulations $\mathrm{Act}^{13}$ to conform with certain administrative procedures unless they are exempted from the terms of the Act. Regulations are ordinarily published in the Canada Gazette within thirty days of being made. They are also ordinarily required to be "laid before Parliament" within fifteen days after such publication. This is the procedure that allows legislators to know of the existence of delegated rules. Although it is possible for a regulation to be exempted from the requirement that it must be laid before Parliament most regulations are not so exempted and this fact provides the opportunity for scrutiny.

In England the methods whereby statutory instruments receive legislative effect vary considerably. Furthermore, statutes often require certain procedures to be executed after a statutory instruments has become law. Thus, some procedural steps are necessary for a statutory instrument to attain the force of law and some are irrelevant to the statutory instrument's attainments of the force of law but yet must still be executed according to the terms of the statute. Statutes sometimes require instruments made under them to be laid before Parliament and of those that are required to be so laid preliminary notice of their existence is demanded in the case of some of them. Some regulations are -required to be laid before Parliament for a specified period and will come into effect at the end of that period unless objection has been taken. Some instruments are required to be laid before the House for forty sitting days during which time they are subject to annulment (and sometimes to modification) by resolution or by prayer. This method of legislative veto is commonly employed in England. The converse situation is that of the "affirmative resolution" method whereby a statutory instrument is laid before the House for a certain period but does not come into effect until the House positively resolves that it shall. It may, alternatively, be provided by the enabling statute that an instrument shall be effective when laid but shall lapse if no affirmative resolution is received. In such a case it would be wise to await the expiry of the period before taking action upon the instrument but where action is taken upon an instrument which is subsequently invalidated the action is taken to have been authorized. Some statutory instruments are required to be laid before Parliament merely for the purpose of notification and are not subject to debate or prayer. Finally, some regulations are required to be sent to the Queen's Printer and almost all the public and general regulations are printed. There remain many enabling statutes which do not require instruments under them to be laid before Parliament or printed. The Donoughmore Committee on Ministers' Powers found it "impossible to discover any rational justification" for this diversity of methods of enactment. ${ }^{14}$ That Committee

14 Report of the Committee on Ministers' Powers (1952) at 42. However, it will quite clearly subject a statutory instrument to a stringent type of control if it is rendered invalid if it does not receive an affirmative resolution of one or both Houses. A less exacting method is to subject the statutory instrument to the possibility of annulment by resolution.

13 R.S.C. 1952, c. 235. 
recommended that it should be a uniform procedure, except where Parliament expressly requires an affirmative resolution, that regulations should be subject to annulment by resolution of either House. Such a resolution, if passed within twenty-eight sitting days of tabling, would ipso facto annul the regulation but would not prejudice the validity of any action already taken under the regulation which is annulled. It will be noticed that although Canada has not formally adopted a uniform method of granting regulation-making power there had been far less difficulty caused by diversity of forms in enabling legislation. Thus, although there are particular forms of the grant of regulations-making power the variety of forms should not give cause for serious disturbance. ${ }^{15}$ Nevertheless, attention should be paid to the form of words employed to grant regulation-making power to a statutory body for it is essential to ensure that the body is the appropriate one and that the power bestowed is not too wide.

\section{Scrutiny of Delegated Legislation}

Scrutiny of legislation should be sustained and continuous in order to be effective. One of the principal benefits of scrutiny is the caution on the part of those making regulations which is induced by it. Such caution would be at least partially sacrified if the scruntiny were of a spasmodic or interrupted nature.

The composition of scrutiny committees has varied considerably. Such a committee may be composed of Members of Parliament, Senators or such lay persons as it may be felt have something to contribute. ${ }^{16}$ Alternatively, it may consist of a combination of these elements.

The British House of Commons has had a Select Committee on statutory instruments since 1944. The general opinion is that this has worked well but that there are some features it would be undesirable to emulate. ${ }^{17}$ There has been no such scrutiny committee of the lower Canada. However, in Canada, the McGuigan Select Committee on Statutory Instruments has recommended that such a Scrutiny Committee should be made available for review of regulations. It made no express recommendation as to the composition of the proposed committee; Votes and Proceedings of the House of Commons, 22nd October, 1969 at 1389.

Supervision of delegated legislation is difficult for members of the House of Commons, either in committee or in the House itself. This is one of the results of the heavy pressure on Parliamentary time. Pressure is not usually so great in the Upper Chamber of Parliament and certain advantages might accrue from enlisting the assistance of Senators to scrutinize delegated legislation. Since 1925 the House of Lords has had a Special Orders Committee whose function has been to consider statutory instruments which have been laid before the House and which require an affirmative resolution. It is charged with the responsibility of reporting certain types of unusual statutory instruments to the House of Lords. This committee examines departmental officials, who

15 On the diversity of forms used in England see, Allen, Law and Orders (3rd ed. 1965), Carr. Delegated Legislation (1921) and Hewart, The New Despotism (1929).

16 The 'Donoughmore Committee on Ministers' Powers recommended the establishment in both Houses, of a small Standing Committee for the purpose of considering both the statutory instruments and their enabling legislation.

17 See Crick, The Reform of Parliament (1965) at 91, where the reservation is expressed that they may not do a thorough job because of the lack of staff. 
may appear with their legal advisers, before it makes its report upon the instrument involved. This is a feature of the work of the committee that could never be achieved by either Chamber of Parliament. The procedure, as a whole, has the advantage of reporting to the House of Lords the statutory instruments that merit their attention. This committee is, however, unfortunately limited in that it is bound to consider only those instruments which require an affirmative resolution of the House of Lords to become effective. The Special Orders Committee has an Australian counterpart in the Standing Committee on Regulation and Ordinances. This committee elicits an explanation of the regulation, and its effect and the reasons for making it from the Government Department concerned before considering the regulation and reporting upon it to the Australian Senate. This committee has power to sit during the Parliamentary recess, which may be a valuable power indeed. The experience of these two committees, particularly the Australian, has been that valuable practical work may be accomplished in the sense that rules not authorized by the Acts under which they are purported to be made, or in some other way not conforming with the guidelines of the committee, may be prevented from becoming law. Furthermore, it is possible to achieve this end without subjecting the Government to a vote which might place the future in jeopardy.

Where a scrutiny committee is composed of either members of the upper chamber or the lower chamber of Parliament, or both, then consideration should be given to its chairmanship. A chairman could either be selected from the political persuasion currently in power or from one of the groups in opposition. There is merit in both of these choices. If the Chairman is a member of the Opposition he may be thought to be free of any disposition to favour the Government. Since the function of the committee is to criticize instruments within certain specified limits an Opposition Chairman might give a stronger impression that this was being done without fear or favour. In the case of the British House of Commons committee a convention has been established that there should be an Opposition Chairman. If the composition of such a committee is that a majority of members are opposition members there will not be the same need to have an Opposition Chairman.

Any scrutiny committee should be assisted by a staff. The result of the sheer weight of numbers of statutory rules and orders is that some permanent official or officials should examine them in order to be able to draw to the attention of the committee the existence of doubtful or objectionable rules and orders. The preliminary examination by officials will have to be carried out with the terms of reference of the committee borne in mind. The practical consideration is that difficulty may be experienced in obtaining qualified staff to fulfil this function.

The result of a scrutiny committee relying upon its staff may be to produce a dependence upon that staff. The consequences of such a dependence is the accrual of power to the staff. This may operate to the benefit or detriment of the public, or it may be entirely neutral. The result may be to detract somewhat from the apparent impartiality of the expressed conclusions of the committee. However, this dependence upon the staff of the committee would not be in respect of matters reported 
on by the committee for these matters would have attracted their attention and consideration. Therefore, it might be said that the danger of dependence upon the staff would lie in what was not specifically mentioned in the committee's report rather than in what was considered there. It is noteworthy that the McGuigan Committee recommended that four Canada Counsel to the committee should be appointed by the Speaker of the House of Commons in order to preserve apparent objectivity.

It would appear that the most appropriate form of scrutiny committee for the consideration of the Government of Canada would be a joint committee of the House of Commons and the Senate. It would thus gain the benefits of participation by both of the Chambers of Parliament and the subjects of its examination could then be all those statutory instruments "laid before Parliament" in accordance with section 7 of the Regulations Act. ${ }^{18}$ If such a scrutiny committee were considered it might be found convenient to have joint chairmen. Such a committee might table an annual report. It might also make reports to both Chambers of Parliament from time to time as it thinks fit to report on particular statutory instruments. It might also be empowered to require appropriate officials from Government Departments and regulationmaking agencies to submit written or oral explanations of a regulation.

It might also refer a regulation back to a Government Department or regulation-making authority with such comment as it sees fit. Neither of these powers would impede or hinder the operation of the statutory instrument. The scrutiny committee would merely make whatever report it felt justified to both Chambers of Parliament, to the Department or Agency concerned or to both. It is anticipated that in the vast majority of cases the scrutiny committee would make no report. Time might be allotted in the House of Commons and in the Senate for the deliberation of motions or prayers relating to statutory instruments.

The terms of reference of the scrutiny committee should include a statement of the function of the committee. This will usually entail the examination of statutory instruments in the light of certain predetermined criteria. ${ }^{19}$ Such criteria might well include the following:

(1) An examination of the instrument to see whether it tends to oust the jurisdiction of the courts. Any instrument effecting an intra vires ouster of the jurisdiction of the courts must be expressly authorized to do so. A vague or general power to make regulations embodied in the statute will not suffice. The British House of Commons Select Committee on Statutory Instruments is empowered to draw the attention of the House to instruments made "in pursuance of an enactment containing specific provisions excluding it from challenge in the courts, either at all times or after the expiration of a specified period". Their experience

18 R.S.C. 1952, c. 235.

10 Which may or may not entall an examination of the substance of the statutory Instrument as well as its form. It is noteworthy that the British House of Commons Select Committee on Statutory Instruments is limited largely to a scrutiny of matters of form. However, it should be noted that in Britain there have been in existence for a long time unofficial groups and committees of members of the House of Commons whose task has been to examine the substance of statutory instruments and the policy of the Government Department or Agency proposing them. Nevertheless, it should be the task of a scrutiny committee to isolate those instruments deserving
attention. Therefore, it is suggested that the scrutiny should include some, or all of the following points, but should not be limited to an examination of form. This will previously have been done by Government Departments, especially the Department of Justice and Privy Councll Office, at an earlier stage. 
has been that it is extremely rare for a statutory instrument to offend this principle. It is thought that this term might be worthy of incorporation in the terms of reference of a scrutiny committee.

(2) The examination might also include the question of whether the instrument appears to make unusual or unexpected use of the powers conferred by the Statute under which it is made. This is a power couched in wide terms and a useful one. One of the functions of a scrutiny committee should be to draw attention to the unexpected or unpredictable use of power. The McGuigan Committee recommended that the proposed Committee should review regulations in light of this criterion.

(3) The examination might include enquiries as to whether there had been an unjustifiable delay in any stage of the making of the regulation. The English Scrutiny Committee of the House of Commons, the Select Committee on Statutory Instruments, had divided this enquiry into tardiness into two distinct parts. It looks at the question of whether the instrument has been delayed in publication or laying or has come into operation prior to laying without prompt notification to $\mathbf{M r}$. Speaker. Since an unjustifiable delay in publication might prevent the public from knowing that a regulation has been made it is regarded as undesirable. One of the ways of preventing this from happening is to ensure that tardiness becomes the subject of comment.

(4) Enquiry might also be made as to whether the statutory instrument has retrospective effect. Rarely would statutory authority exist for such an instrument but this enquiry would appear to be worthy of the attention of a scrutiny committee.

(5) It would also be relevant for the committee to report on statutory instruments which impose a charge on the public revenue. This enquiry should be limited to the situations in which such expenditure is not anticipated by the enabling statute or by an Appropriation Act. Furthermore, it is generally regarded as permissible for a fee to be charged in return for goods and services by way of regulation. Therefore, the enquiry here contemplated might well be limited to a tax or general charge.

(6) A further relevant enquiry would be as to whether the regulation is not clear in meaning. This would appear to be an essential point of reference for any scrutiny committee. Furthermore, a cursory and superficial examination would usually suffice to detect any lack of clarity. Such a brief examination might not suffice in the case of a technical regulation in which case reliance might be placed upon the officials in the Department concerned or upon experts in the field concerned. This enquiry might be limited to those situations in which an instrument is capable of ambiguity. It has been recommended that in Canada adverse comment might be postponed until the regulation-making authority has had a chance to explain the regulation involved. The McGuigan Committee thought that with this reservation this criterion should be employed.

(7) A scrutiny committee might also determine whether provisions of an instrument raise any important questions of policy or principle. This is a broad term of reference and would give any committee, 
within whose terms of reference it might be included, wide political power.

(8) A committee might also discover how far the regulation is founded on precedent. This would appear to be a consideration for the committee but would not be a matter of major importance. It would be useful only insofar as it tended to influence the substantive consideration of whether it ought to be the law of Canada.

(9) A scrutiny committee might determine whether an instrument may be passed by the chamber concerned (or by both Houses) where this is necessary without special attention and whether there ought to be further special inquiry before the appropriate forum proceeds to a decision, and if so, what form the inquiry might take. This point of reference will only be of relevance in the few cases in which an instrument is required or permitted to be passed on by either the House of Commons or the Senate. If the form of the enabling statute does not call for a decision or resolution by either Chamber, the committee might still under this terms of reference, recommend that special attention be paid to a particular regulation.

(10) Such a committee might examine statutory instruments to determine whether they are intra vires the enabling statute or not. This enquiry is undertaken by the House of Lords Special Orders Committee. The Australian Senate Committee on Regulations and Ordinances ascertains more broadly whether the regulations are "in accord with the statute". The scrutiny committee contemplated for the Canadian Federal level of government might consider whether statutory instruments are intra vires the enabling legislation and at the same time consider the constitutionality of the statutory instrument. While this latter consideration is a matter reviewed by the courts from time to time it could conveniently be incorporated in the committee's terms of reference as a safeguard. Such an enquiry by a scrutiny committee would in no way affect the legal status of the regulation. A pronouncement by such a committee as to the legality of the regulation would have no more force than if it had been made by any layman. The only binding arbitration on such a question would have to come from a court unless some special machinery for adjudication were provided by the statute.

(11) Enquiry might be made by a scrutiny committee as to whether the regulations trespass unduly upon personal rights and liberties. This would appear to be a relevant consideration for the scrutiny committee contemplated. It is, of course, an intensely political question. It was felt by the McGuigan Committee that this criterion be employed. Any such trespasses should be effected by statute and not by regulation.

(12) Examination of regulations might also be undertaken to ascertain whether they are concerned with administrative detail alone or whether they amount to substantive legislation which should be a matter for parliamentary enactment. Enabling legislation of various kinds has permitted by the parent statute and other statutes to be amended or altered by a subordinate legislator. While it is generally agreed that this is a dangerous trend it may be difficult to know what other course to pursue in many cases. If the substance of the regulation 
is something that might more properly be contained in a statute or if the regulation does amend a statute (such regulation being made in pursuance of a power to amend the statute) the committee might comment upon it. It might well be appropriate for the committee to append a comment as to whether the regulation was justified.

(13) Examination of the regulations might also be undertaken to determine whether they make the rights and liberties of citizens dependent upon administrative and not judicial decisions. This is something that is not encompassed by the previous enquiry but which is much more specific. It is procedural rather than substantive. It is not necessarily a point of adverse criticism that a regulation does make the rights and liberties of citizens dependent upon administrative decision. In some cases this may be a more convenient or just method of disposition or determination of rights and liberties. However, a close scrutiny of the reasons for, and appropriateness of, the steps must be undertaken.

(14) The scrutiny committee might also examine the subordinate rules to determine whether they exceed the constitutional prerogatives of the federal government. While unconstitutionality and excess of the power conferred by the enabling statute are the only reasons for the invalidation of delegated rules it would appear that this function is already exercised by the courts. The court would appear to be the appropriate body to hear evidence and determine this sort of question. A decision by such a scrutiny committee to the effect that a regulation was unconstitutional would have no effect where the regulation was in force or would inexorably come into force. Whereas the pronouncement of the court to the effect that a regulation is unconstitutional is backed by the authority of the court a similar pronouncement made by a scrutiny committee would have no effect whatsoever unless the status of the regulation could be affected by an adverse vote in either Chamber of Parliament or the committee could in some other way directly or indirectly influence the fate of the regulation.

(15) A scrutiny committee might also examine regulations against such other criteria as they may consider appropriate. The committee might then report on regulations for any substantive reason at all. This vague term of reference would give the committee a completely free hand. ${ }^{20}$. This term of reference might be too wide to be acceptable. The tendency of the inclusion of such a term would be to allow discussion on any matters at all. It would allow the scrutiny committee an absolutely unfettered hand to perform its most important function, that of bringing public presure to bear on objectionable statutory instruments. The inclusion of such a vague term of reference or the granting to the committee of absolutely unfettered powers would in this way transform it into a major political control. With more limited terms of reference a scrutiny committee would be correspondingly limited in its effect. However, even though the effect of the inclusion of such a wide term of reference as is now proposed would be to remove restrictions on the committee it should be remembered that any committee of this sort will have terms of reference, whether they be explicit or not. The benefit

20 This suggestion of this term of reference was made by Professor Brown-John to the Special Committee on Statutory Instruments; Minutes (1969) at 33. 
of having terms of reference spelled out is that they will then act as a guide to the committee, even if (by means of the inclusion of a term like the one now under discussion) that committee is not bound by them.

The question of whether the scrutiny committee should be empowered to judge statutory regulations by any criterion it thinks fit depends on several factors. It would appear to be proper to give the committee a free hand if the other forms of control of the regulationmaking authority are unavailable or are only available in a limited way. There are at present three forms of control; legislative, judicial and political.

The legislative form of control would appear only to be of any use when it is actually exercised or when its exercise is threatened. It may be used by way of conferring only limited powers in the enabling statute. Also, there is always the residual possibility that Parliament may annul a regulation which has been made. The latter form of legislative control will need an Act especially tailored to meet the circumstances, but the former type of legislative control may be governed by general rules which may avert a catastrophe before it occurs. The principal tenet governing the grant of power to make regulations might be to ensure that the power is properly curtailed in the enabling statute to conform with the desires of Parliament. Where the enabling statute grants only power to make a regulation or regulations particularly described in the statute there will be little opportunity for a regulation which makes an unexpected use of the statute. This will be the case provided that the description of the regulation or regulations which may be made contained in the statute is detailed enough and at a low level of abstraction. ${ }^{21}$ In other cases the powers given by enabling statutes are much wider. Such wider powers may take the form of allowing regulations to be made for the attainment of certain objectives or purposes. The purposes contemplated may or may not be reflected in other provisions of the enabling Act. The purposes contemplated are often described in a vague way and the width of such powers demonstrates a lack of legislative restraint. On the other hand, it should be noted that it may be difficult for legislators to be more precise. In other cases the power to make regulations may be limited only to the extent that the regulations must be 'relevant to' or 'in relation to' a certain subject matter. ${ }^{22}$ It would generally be desirable to limit such wide regulation-making powers by appropriate words for the natural result of abstention from legislative control is that judicial control too is automatically excluded.

Judicial control is a powerful form of control because it may result in the effective invalidation of a regulation. Any court with the task of deciding whether a regulation is intra vires or constitutional may have this salutary effect but the limits of judicial intervention are utterly dependent upon the power conferred by the Act itself and consideration of the constitutional position of the Parliament enacting the statute. Not only may the substantive provisions of a statute be so wide

21 S. 27 (3) and s. 30 of the Public Service Superannuation Act, S.C. 1952-53, c. 47 demonstrate the type of circumscribed powers here contemplated.

22 S. 5 of the Fisheries Amendment Act S.C. 1960-61, c. 23 and 5 . 4 of the Aeronautics Act R.S.C. 1952, c. 2, as amended; are examples of wide powers to make regulations for various purposes. 
as to encompass any conceivable regulations but there may also be procedural provisions limiting the jurisdiction of the courts in this regard. The courts may be directly excluded from passing on the regulations involved. Alternatively, the opinion or expression of opinion of the regulation-making authority may be stated by the statute to be conclusive on the matter. ${ }^{23}$ It is generally desirable that Parliament should set definite limits to the exercise of a delegated power for, if it does so, the judiciary will afford the safeguard of seeing that those limits are observed.

The final form of control of delegated legislation is political. In view of the fact that legislative judicial forms of control are often of rather limited value it would seem to be appropriate to give the political form of control a large sphere of influence. No doubt the judicial and legislative controls must inevitably be hampered and that they are fettered from the purest of motives. However, the large number of regulations made necessitates that they should be subjected to some form of discussion. Since political discussion is appropriate for legislation it would probably be appropriate for subordinate legislation. Therefore, if a scrutiny committee is to discuss subordinate legislation at all, it should do so with the broadest mandate. It would not be wise to transfer debates on subordinate legislation from the Chambers of Parliament to a scrutiny committee. However, it might be wise for the committee to be able to anticipate and discuss the matters relating to regulations which will be of interest to the Chambers of Parliament, and ultimately, to the public.

The scrutiny committee contemplated might have some, or all, of the foregoing terms of reference. However, as is noted above, the McGuigan Committee recommended only a few of the foregoing terms of reference for the Scrutiny Committee that they proposed. The rationale and character of the scrutiny committee will obviously depend upon which terms of reference are in fact chosen as appropriate. The scrutiny committee might be empowered to review any statutory instrument laid before Parliament whether it has come into operation or not. This would render a statutory instrument subject to scrutiny even though it had been in force for some time. ${ }^{24}$ Consideration might also be given to investing such a committee with the power of hearing representations from private citizens affected by regulations. This would be a rather large power to bestow on such a committee. It would find itself acting as an Ombudsman. However, as far as the committee was concerned it would still be issuing a report only to the Chambers of Parliament or to the Government Departments or Agencies. The time of the committee would not be taken up too much if representations could only be heard from a person appearing with a Member of the House of Commons and if such Member was responsible

23 This is clearly a wide and autocratic power.

24 The Regulations and Ordinances Committee of the Australian Senate has the power to review regulations at any time after they have been stood referred to the committee. This means that the committee is empowered to examine such an instrument long after Parliament has lost the power of disallowance. Although Parliament would very rarely have the power of disallowance at any time in Canada it might be useful very rarely have the power of disallowance at any time in Canada it might be useful
for the powers of a committee to be continuous. The scrutiny committee of Saskatchfor the powers of a committee to be continuous. The scrutiny committee of Saskatchewan has been given retroactive powers by making it necessary for all regulations made before the existence of the committee to be submitted to it. The penalty for
non-compliance with this requirement is that regulations not submitted are rendered null and void. Neither the English nor the Saskatchewan scrutiny committees appear to have authority to review statutory instruments a second time, or to examine regulations made before the existence of the committee. 
for the conduct of such a person. However, this power might be a rather radical addition tending to alter the character of the committee.

\section{Publicity}

In general, it is thought desirable that publicity should be given to subordinate rules. It is regarded as proper that the public, or the group affected by the regulation, should be informed of the existence of statutory instruments. Wherever feasible, it would be desirable to let the public know of the likelihood of a regulation before it is made. Because the traditional constitutional safeguards that exist with an Act of Parliament are not present at the making of delegated legislation publicity may be all the more essential.

Publicity of delegated legislation may be of two types. It may be antecedent, that is prior to the making of the legislation, or it may be merely communication of what is already law. Antecedent publicity is usually given so that interested groups or individuals may be given a chance to respond to the proposed delegated legislation. Subsequent publicity is almost always designed solely to secure obedience. A substantial difference in the sort of publicity it is desirable to secure for any statutory instrument is made by a determination of how general or specific the order is. In the case of a general order usually only some of the persons affected will be known but the converse applies to orders limited in effect. Although publication prior to a regulation's receiving the force of law is generally conceived of as desirable it is not the usual practice in Canada or elsewhere. Most of the general Acts of the major Commonwealth countries do not require such prior publication. ${ }^{25}$ The difficulties of prior consultation or antecedent publication are largely administrative. It takes a certain amount of time for processing and printing of such regulations. Furthermore, any requirement of prior publication is bound to have exceptions; at least those based on urgency and the need for secrecy. Deliberation and consultation with the parties to be affected may be a visible alternative to prior publication where the parties to be affected by the regulation are largely identifiable.

In the case of publicity to be given to an already binding rule the general maxim is ignorantia juris haud excusat. A citizen is presumed to know the law even if he did not know it and, in fact, was unable to find out what it was. This is often thought to be a harsh rule in the case of statutory instruments. Thus there is felt to be a moral responsibility upon the maker of delegated legislation to make strenouous attempts to notify those affected by such delegated legislation of its existence. The converse proposition, to the effect that an unpublished regulation may not form the basis of a criminal charge, is recognized as a defence by s. $6(3)$ of the Regulations Act ${ }^{20}$ :

"No regulation is invalid by reason only that it was not published in the Canada Gazette, but no person shall be convicted for an offence consisting of a contravention of any regulation that was not published in the Canada Gazette unless

(a) the regulation was, pursuant to section 9, exempted from the operation of subsection (1), or the regulation expressly provides that it shall operate according to its terms prior to publication in the Canada Gazette, and

25 The Australian Act requires at least simultaneous publication unless this requirement is specifically excluded by the enabling Act. See Kersell, Parliamentary Supervision of Delegated Legislation (1960).

20 R.S.C. 1952, c. 235. 
(b) it is proved that at the date of the alleged contravention reasonable steps had been taken for the purpose of bringing the purport of the regulation to the notice of the public, or the persons likely to be affected by it, or of the person charged."

It will be noticed that s. 6(3) (b) provides what might turn out to be a rather wide escape provision, but since the matter is to be decided by a court it may be expected that an even hand will be held between the defendant and the administration. Other jurisdictions having general legislation controlling the use of delegated legislation also make provision for a general exemption from liability where the appropriate form of publicity had not taken place at the time of the act complained of. Often this extends to an exemption from civil, as well as criminal, liability. ${ }^{27}$.

Communication of a statutory instrument may be made in the method most adapted for receipt of the contents by the recipient. Alternatively, publicity might be given to a statutory instrument in a way most administratively convenient for the department or agency charged with the responsibility of making them. A compromise between the interests of the affected party and those of the issuing department or agency might be arrived at. However, this should not be resolved in favour of the total secrecy of statutory instruments. A lack of publicity too is often equated with secrecy. Secrecy tends to give rise to a diminished public confidence in the body making the regulations. ${ }^{28}$ Regulations are often then regarded as arbitrary and the administering agency may even be suspected of making the regulations for an indirect motive. Thus, secrecy should not on principle be used except where absolutely necessary. However, there this no reason to think that this principle has been abused by any regulation-making authority of the canadian federal government in recent years. In general, the provisions for publicity have been quite adequate.

The usual method of bringing a stautory instrument to the attention of the public is by publication in the Canada Gazette. This is provided for by $s .6$ of the Regulations Act. ${ }^{20}$ This is a rather formal way of bringing the regulation to the attention of those affected and more informal methods of informing them are also used whenever possible. These may consist of letters and notices. Such methods may only be used when the regulation is limited temporarily or spatially or where the group or persons affected by these is not extensive.

An additional, if rather perfunctory, method of securing publicity for a statutory instrument is the laying of such instrument before Parliament. The difficulty is that this method does not attract much attention from members of either of the Houses before which it is laid. In theory, however, laying statutory instruments before Parliament is useful in the sense that it gives the opportunity for Parliament to become aware of governmental activity. Without this, Parliamentary supervision would be impossible. With it, Parliamentary supervision is

27 England; Statutory Instruments Act 1946, s. 3. New Zealand has no such provision.

28 It has even been suggested that if the public confidence in the administering agency is shaken, public confidence in the elected representatives will also suffer; Baum Minutes of Proceedings of the Committee on Statutory Instruments (1969) at 129.

29 R.S.C. 1952, c. 235. Section 6 of the Act provides that the regulation should be published within 30 days after it is made in both English and French but that that time limit may be extended by order of the regulation-making authority. According to s. 8 of the Act any regulation published in the Canada Gazette or a consolidation or supplement of it shall be judicially noticed. 
merely unlikely. Often, where there is a requirement that a statutory instrument be tabled it is coupled with the provision of time to debate the instrument. The consequences of inactivity by both Houses of Parliament vary as specified by the enabling statute.

Tabling of an instrument may be effective where there is provision for drawing attention to objectionable instruments and the provision of opportunity for debate in the House of Commons. All three functions must be executed before there can be adequate supervision by a representative body. In Canada, at present, there is a tabling of nearly all regulations. ${ }^{30}$ However, there is no preliminary selection of objectionable instruments. There also is the obstacle that the opportunities for the influence of delegated legislation are currently limited. There is, in fact, no particular time allotted in either the House of Commons or the Senate for the deliberation of statutory instruments. In British, Australian and New Zealand Parliaments special procedures have augmented the sporadic and scattered opportunities to debate regulations that may arise in all Parliamentary systems modelled after that at Westminster. Since the enabling legislation in Canada rarely"11 allows for either Chamber of Parliament to pass upon regulations the approach must be indirect. The indirect opportunities include motions of censure and motions to adjourn debates on Private Member's Bills and on the continuance of enabling legislation.

\section{Reform in Canada}

Both the Federal Government and the Provincial Governments administer statutes which allow the power to make delegated legislation. Since quite a considerable proportion of these rules and regulations affect the public generally it is ncessary to consider the most effective form of control of the rule-making power and the publicity given to rules when made. There can be no concerted effort to keep the legislative, executive and judicial powers rigidly separate. It would be unrealistic to propose the utter separation of, as opposed to retaining the distinction between, these three powers. ${ }^{32}$ The functions are fairly certain

30 Each issue of the Canada Gazette Part II is tabled in the House of Commons by the clerk and in the Senate by the clerk. This is in order to conform with 5.7 of the Regulations Act R.S.C. 1952, c. 235, which reads; "Every regulation shail be laid before Parliament within fifteen days after it is published in the Canada Gazette, or, if Parliament is not then in session, within fifteen days after the commencement of the next ensuing session."

31 Opportunities specifically provided by enabling statutes include the checks of Parliament being required to express disapproval and of it being required to register approval. The latter calls for positive action on the part of Parliament. As an alternative the enabling statute may not specify Parliament as a whole but may indicate either the House of Commons or the Senate. The Export Act R.S.C. 1952, c. 103 provides that "Every regulation shall be laid before both Houses of Parliament within the first fifteen days of the session next after the date thereof, and such regulation shall remain in force until the day immediately succeeding the date of regulation shall remain in force until the day immediately succeeding the date of
prorogation of that session of Parliament and no longer unless during the session prorogation of that session of Parliament and no longer unless during the session
it is approved by resolution of both Houses of Parliament". Section 2 of the Defence Production Act S.C. 1955, c. 52 requires that regulations shall be laid before both Houses of Parliament and may be debated therein. According to s. 4 of the United Nations Act, S.C. 1947, c. 46, regulations made under that Act are to be tabled in Parliament and are subject to annulment within forty days of laying by a resolution of the Senate and House of Commons. A curious provision occurs in the Canada Grain Act, R.S.C. 1952, c. 25, In which the Board of Grain Commissioners is empowered to make orders and regulations. It is further specified by $s$. 17 (2) of the Canada Grain Act that any such regulation may be disallowed by the Governor-inCanada Grain Act that any such regulation may be disallowed by the Governor-inCouncil "and shall cease to have effect as from the date of its disallowance." The is at least accountable to the populace. See also the Transport Act, R.S.C. 1952, c. 271; The Broadcasting Act, S.C. 1958, c. 22; and The Railway Act, R.S.C. 1952, c. 234, s. 53 .

32 This was recognized both by Allen in c. 1 of Law and Order, (3rd ed. 1965) and by the Donoughmore Committee on Ministers' Powers in their Report Cmd. No. 4060 at (1932) at 4. 
to overlap at some points. Indeed, it is apparent that in every common law country legislative and judicial powers have been delegated to the executive.

It is also noteworthy that enabling legislation has not been tightly limited to certain types of regulations which may be made under it. This legislative diffidence has automatically prevented judicial review from being as useful as it might have been. This is naturally the result of enabling legislation for judicial review is then limited to constitutionality and the terms of the legislation.

It would, therefore, appear that the best form of review and control would be the constant scrutiny of delegated legislation performed by a standing committee. Such a committee would be the guardian of the public interest. It would be invested with tremendous political power in that it would be obliged to direct attention to any regulations it regarded as objectionable. In view of the power wielded by such a committee, and having due regard to its composition and chairmanship, it might be desirable to limit its examination to certain particular points of reference. The report of a committee limited to certain points of reference is no less political in nature though the moral indignation of the public which might be aroused as the result of such a report might be more restrained. 